\title{
Protocol
}

\section{Prion Transfection of Yeast}

\author{
Herman K. Edskes, ${ }^{1}$ Dmitry Kryndushkin, ${ }^{2}$ Frank Shewmaker, ${ }^{2}$ and Reed B. Wickner ${ }^{1,3}$ \\ ${ }^{1}$ Laboratory of Biochemistry and Genetics, National Institute of Diabetes and Digestive and Kidney Diseases, \\ National Institutes of Health, Bethesda, Maryland 20892-0830; ${ }^{2}$ Department of Pharmacology, Uniformed \\ Services University for the Health Sciences, Bethesda, Maryland 20814
}

\section{MATERIALS}

Transfection of yeast with amyloid filaments, made from recombinant protein or prepared from extracts of cells infected with a prion, has become an important method in characterizing yeast prions. Here, we describe a method for transmission of [URE3] with Ure2p amyloid that is based on a previously published protocol for transfection with Sup35p filaments to make cells [PSI+]. This method may be used for other prions by changing just the amyloid source, host strain, and plating medium.

It is essential that you consult the appropriate Material Safety Data Sheets and your institution's Environmental Health and Safety Office for proper handling of equipment and hazardous material used in this protocol.

RECIPES: Please see the end of this protocol for recipes indicated by $<R>$. Additional recipes can be found online at http://cshprotocols.cshlp.org/site/recipes.

\section{Reagents}

Complete synthetic medium without leucine and containing adenine (CS + A.1-L) $<\mathrm{R}>$

Complete synthetic medium without leucine and containing adenine sulfate $(\mathrm{CS}+\mathrm{A} 5-\mathrm{L})<\mathrm{R}>$

Lyticase solution $<\mathrm{R}>$

Protein extract or amyloid filaments

Amyloid filaments prepared from bacterially expressed Ure2p (e.g., see Taylor et al. 1999; Brachmann et al. 2005) should be sonicated as described in Step 5 immediately before addition to spheroplasts. Amyloid filaments have been used at concentrations of $0.04-6 \mu \mathrm{g} / \mu \mathrm{L}$.

pRS425 plasmid ( $2 \mu \mathrm{g} / \mu \mathrm{L}$; Christianson et al. 1992)

PTC buffer $<$ R $>$

Single-stranded DNA (10 mg/mL; Worthington-Biochemicals)

SOS medium $<\mathrm{R}>$

ST buffer $<\mathrm{R}>$

STC buffer $<\mathrm{R}>$

Tris-Cl (1 M, pH 7.4)

Yeast strains

BY241 (MATa leu2 trp1 ura3 $P_{D A L 5}: A D E 2 P_{D A L 5}:$ CAN1 kar1)

BY256 (MATa his3 trp1 leu2 $P_{D A L 5}: A D E 2 P_{D A L 5}:$ CAN1 kar1)

YPAD medium $<$ R $>$

${ }^{3}$ Correspondence: wickner@helix.nih.gov

Cite this protocol as Cold Spring Harb Protoc; doi:10.1101/pdb.prot089037 
Equipment

Air supply for blowing cell lysates to new tube after breakage (see Step 2)

Branson 250 Sonifier equipped with a microtip

Conical screw cap microtubes $(2 \mathrm{~mL})$

Glass beads $(0.5 \mathrm{~mm})$

Incubator at $30^{\circ} \mathrm{C}$ and $50^{\circ} \mathrm{C}$

Microcentrifuge

Mini-BeadBeater-8 (Biospec)

Spectrophotometer

Vortex mixer (e.g., Vortex Genie 2)

1. Grow [URE3]-containing cells overnight at $30^{\circ} \mathrm{C}$ in $20 \mathrm{~mL}$ of complete synthetic medium without adenine (i.e., CS + A.1-L without any adenine) to select for maintenance of the prion. Collect the cells, resuspend them in $50 \mathrm{~mL}$ of YPAD to an $\mathrm{OD}_{600}$ of $0.2-0.5$, and grow them for $2-$ 3 doublings at $30^{\circ} \mathrm{C}$. Collect the cells, and wash the cell pellets twice with water. At this point, the pellets can be stored frozen at $-80^{\circ} \mathrm{C}$.

2. Resuspend pellets of [URE3]-containing cells in $600 \mu \mathrm{L}$ of water, and transfer them to a 2-mL conical screw cap microtube. Fill the tubes with 0.5 -mm glass beads, and break the cells for $3 \mathrm{~min}$ in a Mini-BeadBeater- 8 at $4^{\circ} \mathrm{C}$. Briefly centrifuge the tubes, pierce them at the top and bottom, and blow the cell lysates into a clean microcentrifuge tube using an air hose. Clear the lysates by centrifugation for $5 \mathrm{~min}$ at $4^{\circ} \mathrm{C}$, and store them at $-80^{\circ} \mathrm{C}$ until recipient yeasts are ready.

3. Grow recipient [ure-o] cells overnight at $30^{\circ} \mathrm{C}$ in YPAD. Then use $1 \mathrm{~mL}$ of culture to inoculate $50 \mathrm{~mL}$ of $\mathrm{YPAD}$, and grow the cells for $2-3$ doublings at $30^{\circ} \mathrm{C}$. Wash the cells once with $20 \mathrm{~mL}$ of water and twice with $25 \mathrm{~mL}$ of ST buffer, and then resuspend the cells in $5 \mathrm{~mL}$ of ST buffer.

4. Convert the cells into protoplasts by incubation for $40 \mathrm{~min}$ at $30^{\circ} \mathrm{C}$ with $4 \mu \mathrm{L}$ of lyticase solution. Collect the protoplasts by centrifugation at $250 \mathrm{~g}$ for $3 \mathrm{~min}$, wash them two times with $10 \mathrm{~mL}$ of STC buffer, and then resuspend them in $1 \mathrm{~mL}$ of STC buffer.

To reduce shearing, perform all manipulations of protoplasts using pipette tips from which the ends are trimmed to have a wide bore size.

5. Sonicate lysates of [URE3]-containing cells (from Step 2) three times for $45 \mathrm{sec}$ (duty cycle 20\%, output 4) using a Branson 250 Sonifier equipped with a microtip. Keep the lysates on ice between sonications.

6. Add the following to $100 \mu \mathrm{L}$ of protoplasts.

$\begin{array}{ll}\text { Single-stranded DNA }(10 \mu \mathrm{g} / \mu \mathrm{L}) & 1 \mu \mathrm{L} \\ \text { pRS425 plasmid }(2.0 \mu \mathrm{g} / \mu \mathrm{L}) & 2 \mu \mathrm{L} \\ \text { Protein extract or amyloid filaments } & 9 \mu \mathrm{L}\end{array}$

7. Incubate the protoplast/DNA/protein mixture for $10 \mathrm{~min}$ at room temperature. Add $900 \mu \mathrm{L}$ of PTC buffer, and incubate the mixture for $20 \mathrm{~min}$ at room temperature.

8. Collect the protoplasts by centrifugation at $400 \mathrm{~g}$ for $3 \mathrm{~min}$ in a microcentrifuge. Add $200 \mu \mathrm{L}$ of SOS buffer to the pellet, and leave the protoplasts to recover for $30 \mathrm{~min}$ at $30^{\circ} \mathrm{C}$.

9. Pipette the recovered protoplasts into $10 \mathrm{~mL}$ of either CS + A.1-L or CS + A5-L medium kept at $50^{\circ} \mathrm{C}$. Mix each solution by inverting the tubes and directly pour them into Petri dishes containing $20 \mathrm{~mL}$ of the same solidified medium. 
H.K. Edskes et al.

10. Incubate the plates for $6 \mathrm{~d}$ at $30^{\circ} \mathrm{C}$.

$C S+A 5-L$ medium allows all transformants to grow and thus provides a measurement for the transformation efficiency. CS + A.1-L medium is selective for [URE3] cells. Although [URE3] cells do not need adeninesupplemented medium to grow, primary transformants need it to allow phenotypic establishment of the prion (Brachmann et al. 2005).

The first yeast proteins identified genetically to form prions, Ure2p and Sup35p (Wickner 1994), are also the first yeast prion forming proteins shown to form amyloid (King et al. 1997; Taylor et al. 1999). The first attempt to infect yeast with a protein extract from a prion containing strain was made by Sparrer et al. (2000). However, the liposome fusion method was inefficient, and it was not clear if the prions detected were formed in the recipient cell following the introduction of prion domain protein - in effect induction of prion formation by overproduction of the prion domain. Using ballistic transformation Maddelein et al. (2002) showed that introduction of HET-s amyloid into the filamentous fungus Podospora anserine results in infection of mycelium with the [Het-s] prion; introduction of heat-aggregated HET-s did not result in infection. This method has not been used for S. cerevisiae. In 2004 both Tanaka et al. and King et al. created more efficient methods to deliver prion particles into yeast. King et al. used a protoplast fusion system (King and Diaz-Avalos 2004). In this system, protoplasts from two genetically marked strains are incubated with protein extracts. Cell fusion also introduces species present in the medium, including prion particles, into the cells. This method has not found wide application although, in addition to [PSI+], it was shown to work for [PIN+] (Sharma and Liebman 2013). Tanaka et al. created a method that uses plasmid uptake to identify yeast protoplasts that have taken up media contents (Tanaka et al. 2004). In addition to [PSI+], this method has been used to infect cells with prion particles and amyloid of several prion proteins (Ure2p, Rnq1p, Cyc8p, and Swilp) (Brachmann et al. 2005; Patel and Liebman 2007; Patel et al. 2009; Du et al. 2010), and it is our minor modification (for [URE3]) of this method that we describe here.

Yeast strains used for protein transformation experiments aimed at [URE3] contain an ADE2 ORF controlled by the DAL5 promoter. The DAL5 promoter is tightly controlled by Ure2p activity and is activated in [URE3] cells when soluble Ure2p levels drop because of sequestering in amyloid filaments (Schlumpberger et al. 2001; Brachmann et al. 2005). Cells also contain at least one nutritional marker to allow selection for cells that have obtained a yeast replication plasmid. Plasmid uptake is used to identify cells that have taken up buffer contents including Ure2p amyloid filaments (Brachmann et al. 2005). Dramatic differences in transfection efficiency have been noted among yeast strains examined with BY241 (MATa leu2 trp1 ura3 $P_{D A L 5}: A D E 2 P_{D A L 5}: C A N 1$ kar1) and BY256 (MATa his3 trp1 leu2 $P_{D A L 5}: A D E 2 P_{D A L 5}$ :CAN1 kar1) providing particularly good results (Brachmann et al. 2005).

Complete Synthetic Medium without Leucine and containing Adenine (CS + A.1-L)

Yeast nitrogen base without amino acids (Difco) $6.7 \mathrm{~g} / \mathrm{L}$

Dextrose

Agar (for solid medium)

Sorbitol

$20 \mathrm{~g} / \mathrm{L}$

L-Tyrosine

$20 \mathrm{~g} / \mathrm{L}$

L-Arginine $\mathrm{HCl}$

$1 \mathrm{M}$

L-Aspartic acid

$50 \mathrm{mg} / \mathrm{L}$

$50 \mathrm{mg} / \mathrm{L}$

$80 \mathrm{mg} / \mathrm{L}$ 
L-Histidine $\mathrm{HCl}$

L-Isoleucine

L-Lysine $\mathrm{HCl}$

L-Methionine

L-Phenylalanine

L-Threonine

L-Tryptophan

Uracil

L-Valine

Adenine hemisulphate
$20 \mathrm{mg} / \mathrm{L}$

$50 \mathrm{mg} / \mathrm{L}$

$50 \mathrm{mg} / \mathrm{L}$

$20 \mathrm{mg} / \mathrm{L}$

$50 \mathrm{mg} / \mathrm{L}$

$100 \mathrm{mg} / \mathrm{L}$

$50 \mathrm{mg} / \mathrm{L}$

$20 \mathrm{mg} / \mathrm{L}$

$140 \mathrm{mg} / \mathrm{L}$

$0.1 \mathrm{mg} / \mathrm{L}$

Dissolve the amino acid L-tyrosine first. (When it is added according to its alphabetical position it will not go into solution.) Autoclave. For solid medium, add $20 \mathrm{~mL}$ to each Petri plate. Store at $4^{\circ} \mathrm{C}$ (this is stable for at least $6 \mathrm{mo}$ ).

Complete Synthetic Medium without Leucine and containing Adenine Sulfate (CS + A5-L)

Yeast nitrogen base without amino acids (Difco)

Adenine sulfate

Dextrose

Agar (for solid medium)

Sorbitol

L-Tyrosine

L-Arginine $\mathrm{HCl}$

L-Aspartic acid

L-Histidine $\mathrm{HCl}$

L-Isoleucine

L-Lysine $\mathrm{HCl}$

L-Methionine

L-Phenylalanine

L-Threonine

L-Tryptophan

Uracil

L-Valine

Adenine hemisulphate

$$
\begin{array}{r}
6.7 \mathrm{~g} / \mathrm{L} \\
5 \mathrm{mg} / \mathrm{L} \\
20 \mathrm{~g} / \mathrm{L} \\
20 \mathrm{~g} / \mathrm{L} \\
1 \mathrm{M} \\
50 \mathrm{mg} / \mathrm{L} \\
50 \mathrm{mg} / \mathrm{L} \\
80 \mathrm{mg} / \mathrm{L} \\
20 \mathrm{mg} / \mathrm{L} \\
50 \mathrm{mg} / \mathrm{L} \\
50 \mathrm{mg} / \mathrm{L} \\
20 \mathrm{mg} / \mathrm{L} \\
50 \mathrm{mg} / \mathrm{L} \\
100 \mathrm{mg} / \mathrm{L} \\
50 \mathrm{mg} / \mathrm{L} \\
20 \mathrm{mg} / \mathrm{L} \\
140 \mathrm{mg} / \mathrm{L} \\
0.1 \mathrm{mg} / \mathrm{L}
\end{array}
$$

Dissolve the amino acid L-tyrosine first. (When it is added according to its alphabetical position it will not go into solution.) Autoclave. For solid medium, add $20 \mathrm{~mL}$ to each Petri plate. Store at $4^{\circ} \mathrm{C}$ (this is stable for at least $6 \mathrm{mo}$ ).

Lyticase Solution

Reagent

Final concentration

Lyticase (Sigma-Aldrich L2524)

Glycerol

25 units $/ \mu \mathrm{L}$

$20 \%$

Tris-Cl (pH 7.4)

$10 \mathrm{~mm}$

Store at $4^{\circ} \mathrm{C}$ (this is stable for at least $6 \mathrm{mo}$ ).

PTC Buffer

Reagent

Final concentration

PEG8000

Tris-HCl (pH 7.4)

$\mathrm{CaCl}_{2}$

$20 \%(\mathrm{w} / \mathrm{v})$

$10 \mathrm{~mm}$

$10 \mathrm{~mm}$

Store at $4{ }^{\circ} \mathrm{C}$ (this is stable for at least $6 \mathrm{mo}$ ). 
H.K. Edskes et al.

SOS Medium

Reagent

Final concentration

Sorbitol

$1 \mathrm{M}$

$\mathrm{CaCl}_{2}$

$7 \mathrm{mM}$

Yeast extract

$3.3 \mathrm{~g} / \mathrm{L}$

Peptone

$6.7 \mathrm{~g} / \mathrm{L}$

Glucose

$6.7 \mathrm{~g} / \mathrm{L}$

Store at $4^{\circ} \mathrm{C}$ (this is stable for at least $6 \mathrm{mo}$ ).

\section{ST Buffer}

Reagent

Final concentration

Sorbitol

$1 \mathrm{M}$

Tris-HCl (pH 7.4)

$10 \mathrm{~mm}$

Store at $4^{\circ} \mathrm{C}$ (this is stable for at least $6 \mathrm{mo}$ ).

STC Buffer

Reagent

Final concentration

Sorbitol

$1 \mathrm{M}$

Tris-HCl (pH 7.4)

$10 \mathrm{~mm}$

$\mathrm{CaCl}_{2}$

$10 \mathrm{~mm}$

Store at $4^{\circ} \mathrm{C}$ (this is stable for at least $6 \mathrm{mo}$ ).

YPAD Medium

Reagent

Final concentration

Yeast extract

$10 \mathrm{~g} / \mathrm{L}$

Peptone

$20 \mathrm{~g} / \mathrm{L}$

Dextrose

$20 \mathrm{~g} / \mathrm{L}$

Adenine sulfate

$0.4 \mathrm{~g} / \mathrm{L}$

Agar (for solid plates)

$20 \mathrm{~g} / \mathrm{L}$

Store at $4^{\circ} \mathrm{C}$ (this is stable for at least $6 \mathrm{mo}$ ).

This work was supported in part by the Intramural Program of the National Institute of Diabetes and Digestive and Kidney Diseases of the National Institutes of Health.

\section{REFERENCES}

Brachmann A, Baxa U, Wickner RB. 2005. Prion generation in vitro: Amyloid of Ure2p is infectious. EMBO J 24: 3082-3092.

Christianson TW, Sikorski RS, Dante M, Shero JH, Hieter P. 1992. Multifunctional yeast high-copy-number shuttle vectors. Gene 110: 119-122.

Du Z, Crow ET, Kang HS, Li L. 2010. Distinct subregions of Swil manifest striking differences in prion transmission and SWI/SNF function. $\mathrm{Mol}$ Cell Biol 30: 4644-4655.

King CY, Diaz-Avalos R. 2004. Protein-only transmission of three yeast prion strains. Nature 428: 319-323.
King C-Y, Tittmann P, Gross H, Gebert R, Aebi M, Wuthrich K. 1997. Prion-inducing domain 2-114 of yeast Sup35 protein transforms in vitro into amyloid-like filaments. Proc Natl Acad Sci 94: 6618-6622.

Maddelein ML, Dos Reis S, Duvezin-Caubet S, Coulary-Salin B, Saupe SJ. 2002. Amyloid aggregates of the HET-s prion protein are infectious. Proc Natl Acad Sci 99: 7402-7407.

Patel BK, Liebman SW. 2007. "Prion proof” for $\left[P I N^{+}\right]$: Infection with in vitro-made amyloid aggregates of Rnq1p-(132-405) induces $\left[P I N^{+}\right]$. $J$ Mol Biol 365: 773-782. 
Patel BK, Gavin-Smyth J, Liebman SW. 2009. The yeast global transcriptional co-repressor protein Cyc8 can propagate as a prion. Nat Cell Biol 11: 344-349.

Schlumpberger M, Prusiner SB, Herskowitz I. 2001. Induction of distinct [URE3] yeast prion strains. Mol Cell Biol 21: 7035-7046.

Sharma J, Liebman SW. 2013. Exploring the basis of $\left[P I N^{+}\right]$variant differences in $\left[\mathrm{PSI}^{+}\right]$induction. J Mol Biol 425: 3046-3059.

Sparrer HE, Santoso A, Szoka FC, Weissman JS. 2000. Evidence for the prion hypothesis: Induction of the yeast $\left[\mathrm{PSI}^{+}\right]$factor by in vitro-converted Sup35 protein. Science 289: 595-599.
Tanaka M, Chien P, Naber N, Cooke R, Weissman JS. 2004. Conformational variations in an infectious protein determine prion strain differences. Nature 428: 323-328.

Taylor KL, Cheng N, Williams RW, Steven AC, Wickner RB. 1999. Prion domain initiation of amyloid formation in vitro from native Ure2p. Science 283: 1339-1343.

Wickner RB. 1994. [URE3] as an altered URE2 protein: Evidence for a prion analog in S. cerevisiae. Science 264: 566-569. 


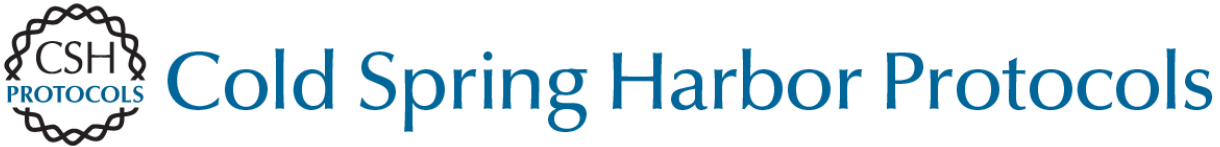

\section{Prion Transfection of Yeast}

Herman K. Edskes, Dmitry Kryndushkin, Frank Shewmaker and Reed B. Wickner

Cold Spring Harb Protoc; doi: 10.1101/pdb.prot089037

\begin{tabular}{cc}
$\begin{array}{r}\text { Email Alerting } \\
\text { Service }\end{array}$ & Receive free email alerts when new articles cite this article - click here. \\
\hline $\begin{array}{c}\text { Subject } \\
\text { Categories }\end{array}$ & $\begin{array}{c}\text { Browse articles on similar topics from Cold Spring Harbor Protocols. } \\
\text { Cell Biology, general (1382 articles) } \\
\text { Yeast (288 articles) }\end{array}$ \\
\hline
\end{tabular}

